\title{
Evaluation of Groundwater Recharge based on Climate Change: A Case Study at Baung's Watershed, Kota Bharu, Kelantan
}

(Penilaian Aliran Masuk Air Bawah Tanah berdasarkan Perubahan Iklim: Suatu Kajian Kes di Lembangan Baung, Kota Bharu, Kelantan)

\author{
NAZRi Ebrahim, Mohamed Azwan M.Z.*, Md Rowshon K. \& NurulHuda K.
}

\begin{abstract}
The soil water assessment tool (SWAT) is a continuous and distributed hydrologic model created to simulate the effect of land management practices on water in the watershed. Understanding relationship of water extraction of groundwater can lead to better watershed management. The main problem in this study is the complexity of recharge processes and limited observations in groundwater recharge in Malaysia makes it difficult to quantify. This study was done at Baung's watershed (BW) which can be considered as an ungauged watershed. The estimation of groundwater recharge in $B W$ was done using SWAT. However, BW cannot be calibrated due to lack of streams station availability but the uncalibrated SWAT able to provide satisfactory predictions on hydrologic budget. A framework for SWAT input data including hydrography, terrain, land-use, soil, and weather for BW was then focused in order to achieve the model simulation for ungauged basins. The results emphasize the importance and prospects of using accurate spatial input data for the physically based SWAT model. Normal condition, extreme-low precipitation and future in land-use development represented as scenarios 1, 2, and 3 were evaluated in this study. These conditions give different groundwater recharge rate as different scenarios give different impact to groundwater. Model was found to produce a reliable estimation of groundwater recharge of $405 \mathrm{~mm} /$ year (14.6\%), $194.12 \mathrm{~mm} /$ year (11.1\%), and $214.23 \mathrm{~mm} /$ year (7.7\%) for scenarios 1, 2, and 3, respectively. In conclusion, it suggested that groundwater recharge should not be assumed always 6\% of annual rainfall in Malaysia as the factors influencing groundwater recharge need to be took into consideration in assisting groundwater exploration and management.
\end{abstract}

Keywords: Geophysical; groundwater recharge; soil and water assessment tools; soil investigation; ungauged watershed

ABSTRAK

Alat penilaian air dan tanah (SWAT) adalah model hidrologi yang berterusan dan teragih telah dicipta untuk membuat simulasi terhadap kesan amalan pengurusan tanah ke atas lembangan. Pemahaman tentang hubungan pengekstrakan air bawah tanah membawa kepada pengurusan lembangan yang lebih baik. Masalah utama bagi kajian ini adalah proses aliran masuk yang rumit dan pemerhatian yang terhad dalam aliran masuk air bawah tanah di Malaysia yang menjadikannya sukar untuk dihitung. Kajian ini telah dijalankan di Lembangan Baung (BW) yang boleh dianggap sebagai lembangan yang tiada tolok. Anggaran aliran masuk air bawah tanah di BW telah dilakukan menggunakan SWAT. Walau bagaimanapun, BW tidak dapat ditentukur kerana kekurangan stesen sungai yang sediada tetapi SWAT yang tidak ditentukur mampu memberikan ramalan yang memuaskan mengenai anggaran hidrologi. Kerangka kerja untuk data masukan SWAT termasuklah hidrografi, maklumat guna tanah, maklumat tanah dan cuaca untuk BW telah difokuskan untuk mencapai simulasi model bagi lembangan tidak bertolok. Hasil daripada keputusan telah menekan kepentingan dan prospek menggunakan data masukan geografi yang tepat untuk model SWAT berasaskan fizikal. Senario 1, 2 dan 3, masing-masing mewakili keadaan yang normal, hujan yang terlampau rendah, dan pembangunan penggunaan tanah pada masa hadapan telah dinilai dalam kajian ini. Keadaan ini memberikan kadar aliran masuk air bawah tanah yang berbeza-beza kerana senario yang berbeza memberikan impak yang berbeza kepada air bawah tanah. Model telah didapati menghasilkan anggaran aliran masuk air bawah tanah sebanyak 405 mm/tahun (14.6\%), $194.12 \mathrm{~mm} / \mathrm{tahun}(11.1 \%)$ dan $214.23 \mathrm{~mm} /$ tahun (7.7\%), masing-masing bagi senario 1, 2 dan 3. Kesimpulannya, adalah dicadangkan bahawa aliran masuk air bawah tanah tidak sepatut dianggap selalu 6\% daripada hujan tahunan di Malaysia kerana faktor yang mempengaruhi aliran masuk air bawah tanah perlu diambil kira dalam membantu penerokaan dan pengurusan air bawah tanah.

Kata kunci: Alat penilaian air dan tanah; aliran masuk air bawah tanah; geofizikal; kajian tanah; lembangan tidak bertolok 


\section{INTRODUCTION}

Environmental problems have slowly spread to many of Malaysia's river basins with associated problems such as flooding, water pollution and sedimentation (Salmiati \& Salim 2017). In order to maintain the quality of water resources, it is important to develop the requisite knowledge and skills to safeguard our catchments and river basins without altering socioeconomic growth. Conducting field tests and gathering long-term data can be expensive (Burchfield 1996; Osang et al. 2013). Therefore, the utilization of modelling becomes crucial. Modelling methods are well established to help relevant authorities, academics, engineers, and policy makers in Malaysia forecast the future impact of urban development on the quantity and quality of river water in a given basin.

Rapid economic growth and infrastructural development in Malaysia increased the demand for freshwater, in which groundwater contribute less than $10 \%$ of the water supply. States located at East coast of Peninsular Malaysia (Kelantan, Pahang and Terengganu) and eastern part (Sabah and Sarawak) highly dependent on groundwater as freshwater source. $70 \%$ of the freshwater supply account for domestic used. While the other 25 and 5\% supplied for industrial and agricultural uses, respectively. Kelantan and Perlis highly utilized groundwater as freshwater source, whereas other states such as Terengganu, Pahang, Sarawak, and Sabah used groundwater as a supplement in their water supply system. Based on Minerals and Geoscience Department (JMG), a total of 9,817 groundwater wells were drilled all over Malaysia in which Kelantan has the highest number of drills (1,955). Manap et al. (2014) later reported that $70 \%$ of water supply in Kelantan, primarily in Kota Bharu area originated from the groundwater. Suratman (2014) added that, rural population depends greatly on groundwater for their daily requirement. Similarly, small islands area such as Kapas and Manukan rely on groundwater as freshwater source. For small island, the dependency of freshwater water supply from groundwater happened due to the geological and topographical nature as the existence of surface water in such area is virtually impossible (Kura et al. 2018).

Groundwater is found in the Earth's subsurface, as a dynamic system. It happens and travels under the influence of certain different factors that are researched in different science fields such as hydrogeology, hydrology, and climatology. In this study, recharge is an important parameter that needs to be evaluated more thoroughly among the variables influencing the situation and the fluctuation of the groundwater. Factors such as meteorology, soil conditions, surface cover, and slope affect recharge on a small and large scale. The estimation of groundwater recharge from precipitation is a principal part of hydrologry and hydrogeology. Accurate quantification of recharge rate is imperative to the proper management and protection of valuable groundwater resources. In water resource investigations, groundwater models are used to simulate the flow of water in aquifers, and when calibrated, may be used to simulate the long-term behaviour of an aquifer under various management schemes.

Assumptions which underlie methods of estimating groundwater recharge rates for the proper application of any system, a complete understanding of theories and conclusions is necessary. Good practice demands that recharge estimation techniques are calibrated at individual sites to the conceptual model of recharge processes to determine that the hypotheses that underlie the techniques are compatible with conceptual models. Recharge is characterized in this as the downward flow of water entering the water table, leading to storage of groundwater.

Earth's surface can be divided into areas where some of the surface water flows into the saturated zone and other areas where water flows from saturated zone to the ground surface. Area where water exits the saturated zone were referred to as recharge areas. Most precipitation evaporates from soil surface, transpiration process from plants and flows over the surface as runoff (Khalilian \& Shahvari 2019). Common groundwater recharge rate was assumed to be $6 \%$ from annual rainfall in Malaysia (Federation of Malaysian Consumers Associations (FOMCA 2009) without taking consideration on the landuse and environmental effect. Sg Baung was located near Tg Mas Water Treatment Plant that contributed to the Baung's watershed (BW). Such phenomenon already had effect on the recharge rate which will not suite the early assumption of $6 \%$. Moreover, groundwater recharge for four monsoon months was assumed to be a certain percentage of normal rainfall of that month which does not exceed $26 \%$ of normal monsoon rainfall (Mali \& Singh 2017).

For these watershed problems, SWAT was also developed to predict the impact of management practices on water, sediment, and agricultural chemicals in watersheds comprising different soils, land-use, and management conditions over long time periods. The impact of land-use changes and climate change as well as their combined/interactive effect on water resources can also be predicted through SWAT. SWAT was also coupled with ecosystem models to study the trade-offs between water quality and ecosystem services. Application of SWAT model also included the case of arid and semiarid watersheds. Remote sensed data provides valuable geographical and real-time knowledge about natural resources and physical parameters. The present study was carried out on the implementation of the SWAT model, which combines GIS knowledge with the attribute database to approximate the recharge rate. 


\section{MATERIALS AND METHODS}

\section{STUDY AREA DESCRIPTION}

The study area was located at Kota Bahru, Kelantan. Kota Bharu is located at North Kelantan which is topographically dominated by a flat coastal plain with an elevation of less than $75 \mathrm{~m}$ above sea level (amsl) and located on the east coast of the Malaya Peninsula (Tahir et al. 2009). In this research study, the proposed new volume of groundwater extraction was done at WTP Tg Mas, Kota Bharu located at 197372 m E, 679277 m N. WTP supply clean water to Kota Bharu area with the amount of water supplied is approximately 10 MLD. However, the populations in Kelantan increased from 1.54 million in 2010 (491,237 in Kota Bharu) to 1.89 million in 2018 elucidating the increase in water demand. Thus, the water supply increased to 30 MLD. Figure 1 shows the study area of WTP Tg Mas, Kelantan. Sg Baung was located besides WTP Tg Mas and potentially to give an amount of groundwater recharge. Thus, a preliminary study on groundwater recharge was done on Baung's Watershed (BW) area.

Based on the meteorological data, the maximum and minimum daily air temperatures are 33.2 and $23.7^{\circ} \mathrm{C}$ respectively (MMD 2018). Table 1 describes the general meteorological characteristics of study area from year 2007 to 2016 data, which include humidity, temperature, wind speed, solar radiation, and precipitation.

From geological point of view, the study area mainly consists of sandy clay, clay, and sandy silt soils from geotechnical survey consists of geophysical test and soil investigations of Tube well (TW 1) and TW2 was done at the study area. The upper part of profile consists of unsaturated zone while groundwater table is located in silty clay and silty sand clay layers.

\section{SWAT MODEL}

SWAT was used to simulate BW the hydrologic processes such as precipitation, surface runoff, infiltration, evapotranspiration, lateral flow, percolation, and groundwater flow which is based on the water balance equation. Ultimately groundwater recharge could be estimated. Process of developing BW was done by overlapping all basic inputs required for SWAT includes Digital elevation Models (DEM), soil map and land-use map. Weather database for BW were include of hydrometeorological data such as rainfall, temperature, relative humidity, and wind speed as shown in Table 1. Soil database for SWAT were referred to soil investigation and geophysical test report. The model simulated various hydrologic processes in the root zone and the shallow aquifer and calculates the recharge to the deep aquifer on BW.

\section{RESULTS AND DISCUSSION}

\section{GEOTECHNICAL SURVEY}

Electrical resistivity profile was done to identify the geological structure information. The soil resistivity was conducted to see the geology type and possible groundwater storage for the area. Resistivity analysis was able to transversely map the soil layer based on the resistance value. At higher resistance more than 50000 ohm-m the soil considered the hard rock, while at lower resistivity $<10 \mathrm{ohm}-\mathrm{m}$ the soil was potentially to have more water (Ebrahim et al. 2019). An accurate interpretation was done with geological material verified by cross checking with soil investigation (Saad et al. 2012).

From the result in Figure 3, resistivity 1 and SI (TW1) referring to the data inside WTP Tg Mas, while Resistivity 2 and SI (TW2) referred to data in area besides Sg Baung. It was shown that Resistivity 1 (Figure 3(a)) values ranging 50-100 ohm-m and 10-50 ohm at depth of 0-1.5 $\mathrm{m}$ and 1.5-12 m represented a Sandy clay and Clay soil, respectively, supporting the data on SI. Resistivity 2 (Figure 3(b)) with 10-30 ohm-m at depth 0-12 m represented a Sandy Clay soil. Based on the obtained data regardless of the different point of data taken by the geological structure in BW at similar depth resulted with similar soil structure. The result obtained were in good correlation with prior study (Saad et al. 2012) in which resistivity ranging value of 37-88 ohm-m and 57-109 ohm-m represent a geological structure of Sandy Clay and Clay, respectively.

\section{SIMULATION USING SWAT}

SWAT was conducted to estimate and predict value of groundwater recharge for the BW. Different conditions of normal, extreme low precipitation and in future development were assessed in this study.

In the present study, ungauged watershed cannot be calibrated due to lack of river discharge data. The uncalibrated model needs to be evaluated in order to show the performance of developed model (Srinivasan et al. 2010). Validation is the process of evaluating the final product of the model in order to check whether the software meets the expectations and requirements. In this study, validation was done by measuring river discharge at $\mathrm{Sg}$ Baung by daily process. Regression analysis was done in order to compare the observed river discharge and predicted discharge from the model. The coefficient of determination, $\mathrm{R}^{2}$, is a measure of how well the regression model describes the observed data. Based on Figure 4, the $\mathrm{R}^{2}(0.9676)$ daily shows that simulated model was in a good fit with observed data as it shows the positive relationship with the accuracy of the regression model is close to 1 (Schneider et al. 2010). In comparison, Golmohammadi et al. (2014), found a $R^{2}(0.41)$ daily 
calibration was poor compared to the monthly calibration $\mathrm{R}^{2}(0.64)$ which may be affected by the model input parameters.

Scenario 1: Normal condition

Normal condition referring to the current land-use and normal environment conditions of the selected study area. Table 2 shows the result of groundwater recharge for normal condition. The groundwater recharge in $\mathrm{BW}$ was equal to $405 \mathrm{~mm} /$ year. Kota Bharu having a recharge of $484.3 \mathrm{~mm} /$ year as stated by Tahir et al. (2014).

Figure 5 shows the water balance in BW showing the yearly precipitation as rainfall was $2783.3 \mathrm{~mm} /$ year. Based on calculation, the groundwater recharge equal to $14.6 \%$ from effective rainfall. Saghravani et al. (2013) study on groundwater recharge in tropical climate taking Selangor as study area in Malaysia resulted with groundwater recharge of $12.25 \%$ obtained using SWAT model. In the meantime, Tahir et al. (2014) prior study in Kelantan obtained a value of $19.4 \%$. The present study, BW located in an area which experienced a monsoon month. The monsoon month also included as normal condition. Mali and Singh (2017) stated that groundwater recharged in normal monsoon condition will not exceed $26 \%$. Thus, present value showed that the model was not overestimate the water balance.

Scenario 2: Extreme low precipitation

Extreme low precipitation conditions indicate the lack of long-term rain and drought. Table 3 shows the result of recharge and evapotranspiration for extreme low precipitation condition. The obtained recharge value (194.12 mm/year) was lower compared to the normal condition which may due to the lower rainfall as supported by Memarian et al. (2014).

Figure 6 shows the water balance during extreme low precipitation in $\mathrm{BW}$. The groundwater recharge obtained was $11.1 \%$ from effective rainfall. The value obtained was lower than normal condition of $14.6 \%$ as the precipitation was $62.8 \%$ lower than normal condition precipitation. This scenario related to El-Nino phenomena and drought condition because of extreme low precipitation. This phenomenon leads to the reduction of groundwater recharge. As studied by Saghravani et al. (2013), added that groundwater recharge will increase and decrease with the intensity of precipitation.

Scenario 3: Future land-use development

In the future, the studied area expected to undergone urbanization. The surface area of BW at fully urbanized will be comprised of concrete structure. This will relatively affect the surface runoff and recharge in BW. From Table 4 , the recharge $(214.23 \mathrm{~mm} /$ year) was lower compared to scenario 1 (405 mm/year). Chahinian et al. (2005) stated that urbanization caused low infiltration despite the high rainfall intensity.

Figure 7 shows water balance of BW in development of land-use. Scenario 3 was compared to scenario 1 because the simulation was done with the same hydrogeological parameters and only different land-use. It was showed that groundwater recharge was highly influenced by the land use changes as the groundwater recharge reduce from $14.6 \%$ in normal condition to $7.7 \%$ effective rainfall in future land use. Flood may potentially happened at urbanized area as the surface run off increase at minimal precipitation changes (Niehoff et al. 2002; Wooldridge et al. 2001).

TABLE 1. Monthly mean climatic characteristic of study area (2007-2016) (DID 2018; MMD 2018)

\begin{tabular}{lcccccc}
\hline Month & Humidity $(\%)$ & $\begin{array}{l}\text { Maximum } \\
\text { temperature }\left({ }^{\circ} \mathrm{C}\right)\end{array}$ & $\begin{array}{l}\text { Minimum } \\
\text { temperature }\left({ }^{\circ} \mathrm{C}\right)\end{array}$ & $\begin{array}{l}\text { Wind } \\
\text { speed } \\
(\mathrm{m} / \mathrm{s})\end{array}$ & $\begin{array}{l}\text { Solar } \\
\text { radiation } \\
(\mathrm{MJm}-2)\end{array}$ & $\begin{array}{l}\text { Precipitation } \\
(\mathrm{mm} / \text { year })\end{array}$ \\
\hline January & 81.4 & 29.5 & 23.7 & 3.0 & 16.8 & 190.0 \\
February & 78.8 & 30.1 & 23.7 & 3.4 & 20.3 & 64.0 \\
March & 78.7 & 31.4 & 24.0 & 2.8 & 23.3 & 180.0 \\
April & 78.5 & 32.7 & 25.3 & 2.4 & 23.1 & 90.0 \\
May & 78.2 & 33.2 & 25.3 & 2.3 & 21.4 & 120.0 \\
June & 80.0 & 32.6 & 24.9 & 2.0 & 19.8 & 130.0 \\
July & 81.1 & 32.2 & 24.5 & 1.9 & 19.6 & 170.0 \\
August & 80.7 & 31.9 & 24.0 & 2.0 & 20.6 & 180.0 \\
September & 79.7 & 32.0 & 24.1 & 2.0 & 20.6 & 150.0 \\
October & 82.7 & 31.2 & 24.1 & 2.0 & 18.4 & 300.0 \\
November & 87.5 & 29.6 & 24.1 & 1.8 & 14.1 & 640.0 \\
December & 84.6 & 29.4 & 24.0 & 3.0 & 14.2 & 630.0 \\
\hline
\end{tabular}


TABLE 2. Result for normal condition

\begin{tabular}{cc}
\hline Recharge $(\mathrm{mm})$ & 405.00 \\
Evapotranspiration $(\mathrm{mm})$ & 882.60 \\
Re-evaporation from shallow aquifer $(\mathrm{mm})$ & 24.97 \\
Return flow $(\mathrm{mm})$ & 357.89 \\
Surface runoff $(\mathrm{mm})$ & 1491.66 \\
Lateral flow $(\mathrm{mm})$ & 0.74 \\
\hline
\end{tabular}

TABLE 3. Result for extreme low precipitation

\begin{tabular}{cc}
\hline Recharge $(\mathrm{mm})$ & 194.12 \\
Evapotranspiration $(\mathrm{mm})$ & 840.46 \\
Re-evaporation from shallow aquifer $(\mathrm{mm})$ & 24.06 \\
Return flow $(\mathrm{mm})$ & 141.8 \\
Surface runoff $(\mathrm{mm})$ & 655.13 \\
Lateral flow $(\mathrm{mm})$ & 0.14 \\
\hline
\end{tabular}

TABLE 4. Result for future land-use

\begin{tabular}{cc}
\hline Recharge $(\mathrm{mm})$ & 214.23 \\
Evapotranspiration $(\mathrm{mm})$ & 859.50 \\
Re-evaporation from shallow aquifer $(\mathrm{mm})$ & 24.97 \\
Return flow $(\mathrm{mm})$ & 176.94 \\
Surface runoff $(\mathrm{mm})$ & 1706.54 \\
Lateral flow $(\mathrm{mm})$ & 0.52 \\
\hline
\end{tabular}

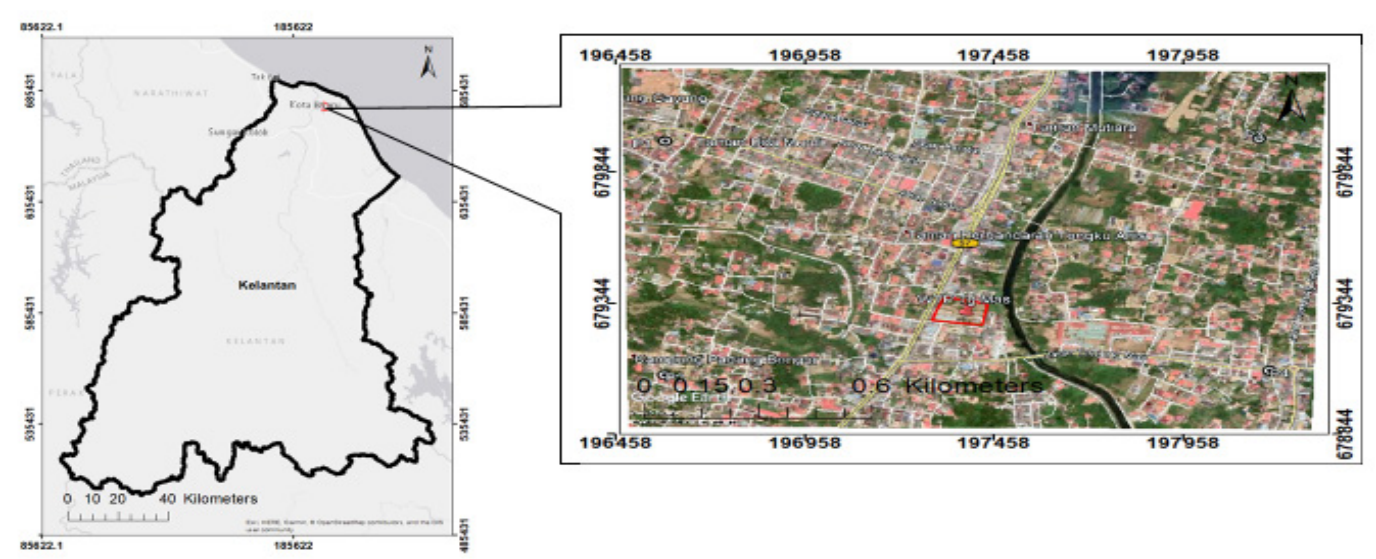

FIGURE 1. Study area at WTP Tg Mas, Kota Bharu, Kelantan 


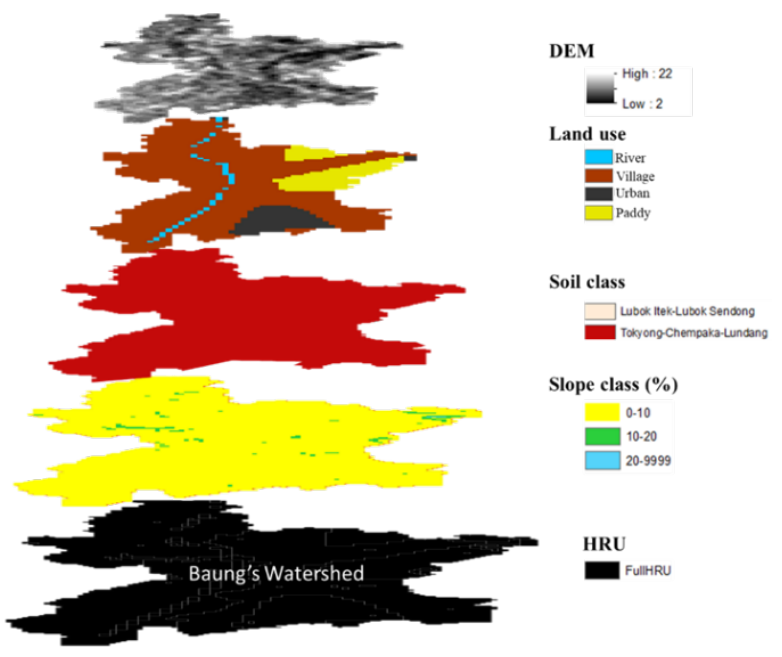

FIGURE 2. SWAT process for BW area

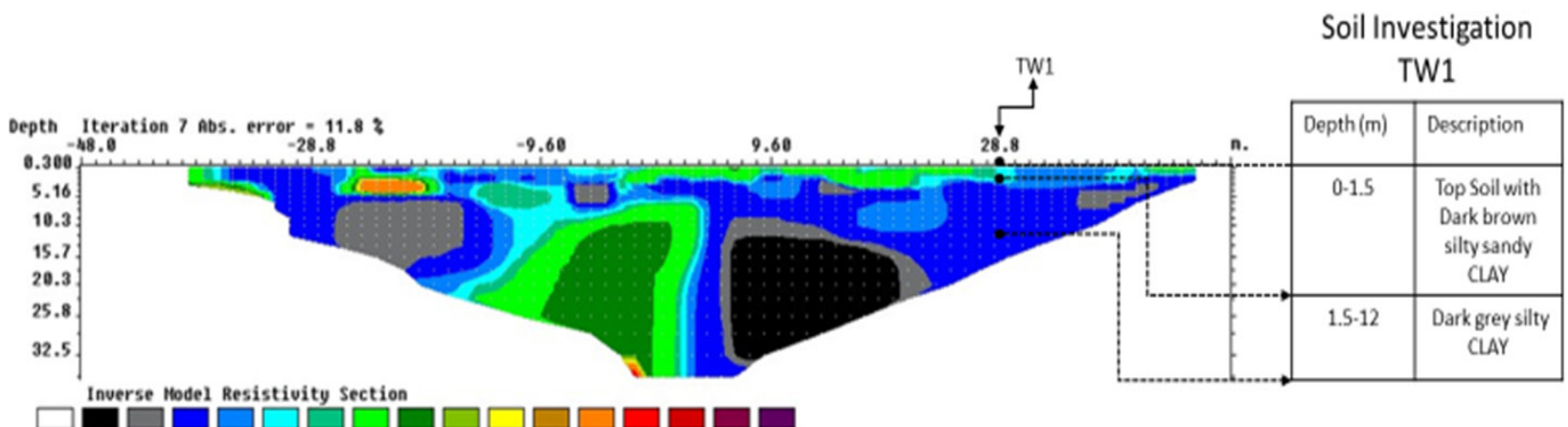
$\square_{1.00} \square_{10.0} \square_{50.0} \square_{100} \square_{500} \square \square_{900} \square_{2000} \square_{5000} \square^{-}$

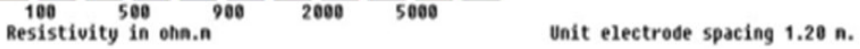

(a) Resistivity 1

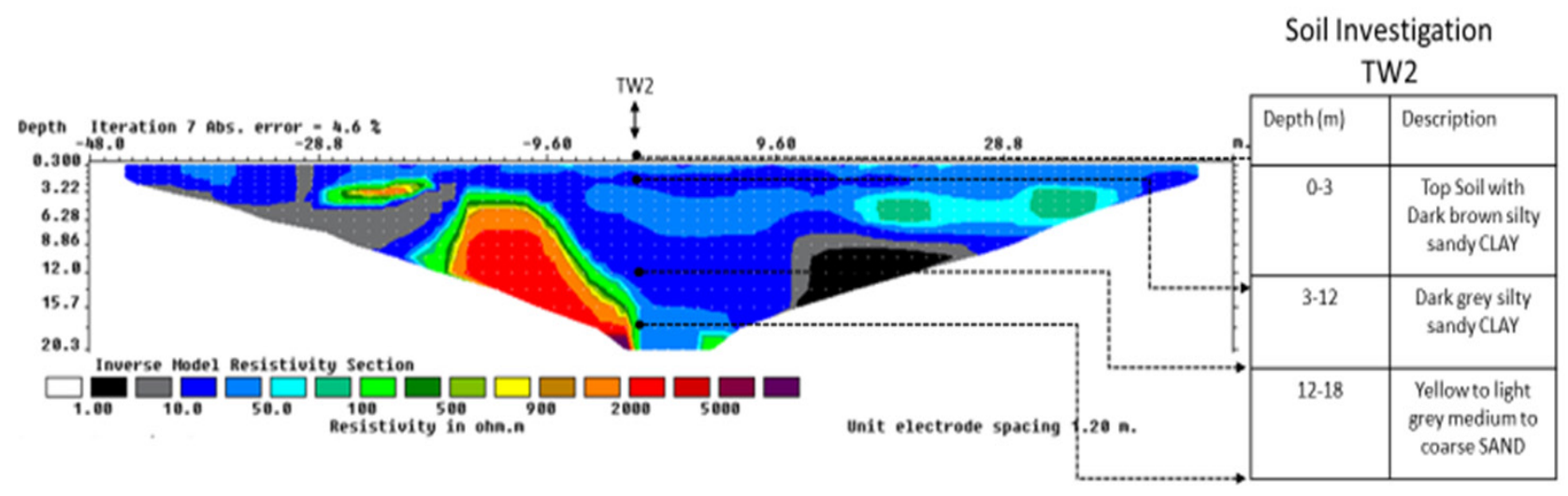

(b) Resistivity 2

FIGURE 3. (a) Resistivity 1, (b) Resistivity 2 


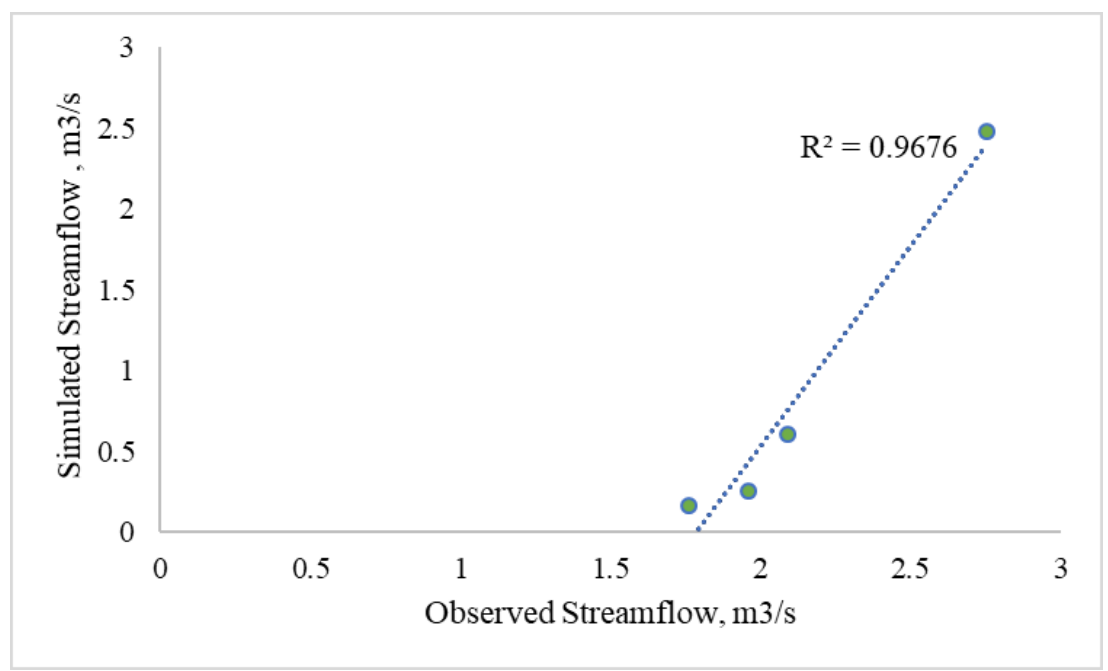

FIGURE 4. Coefficient of determination, R2

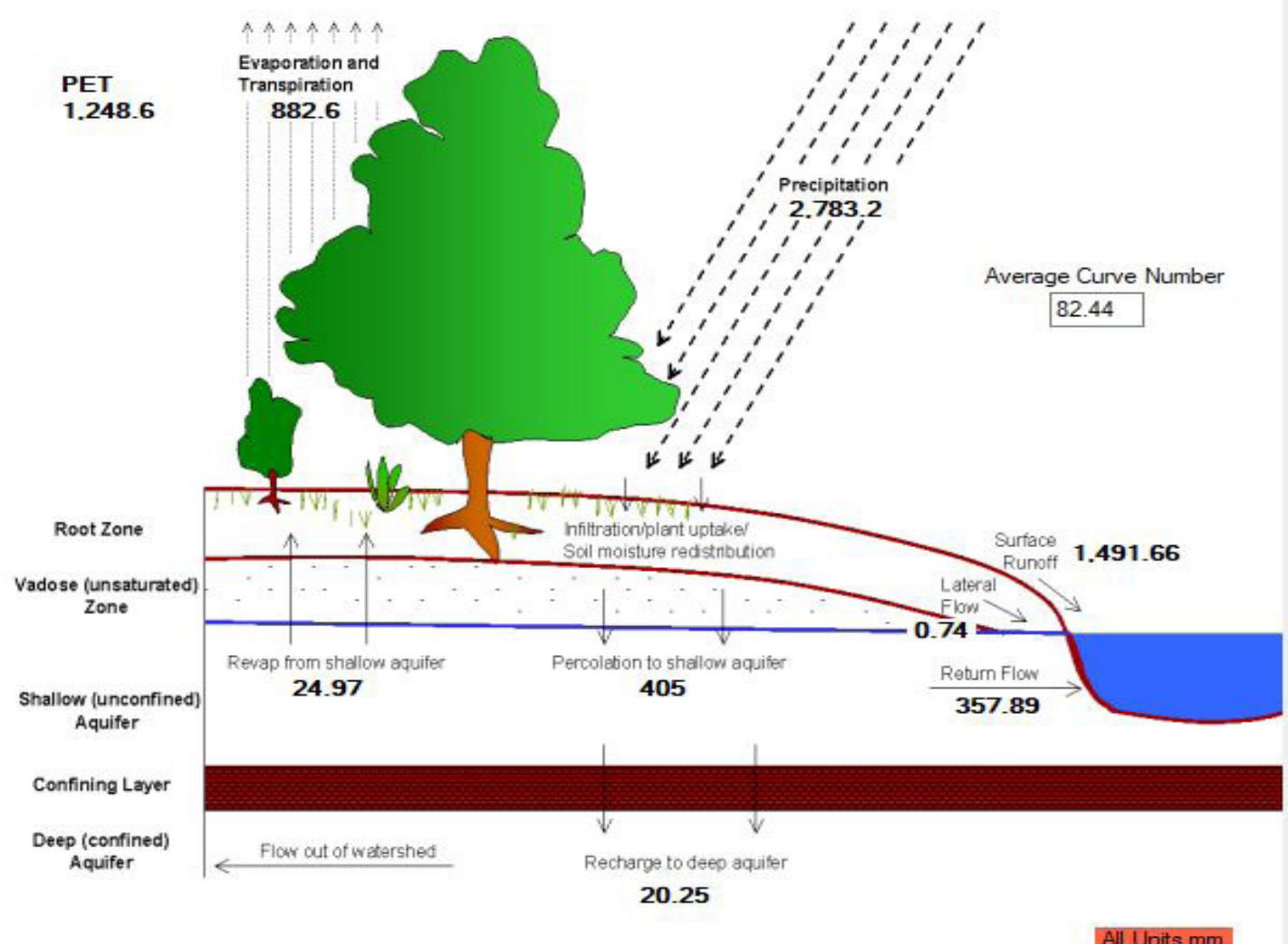

FIGURE 5. Hydrological condition in normal state 


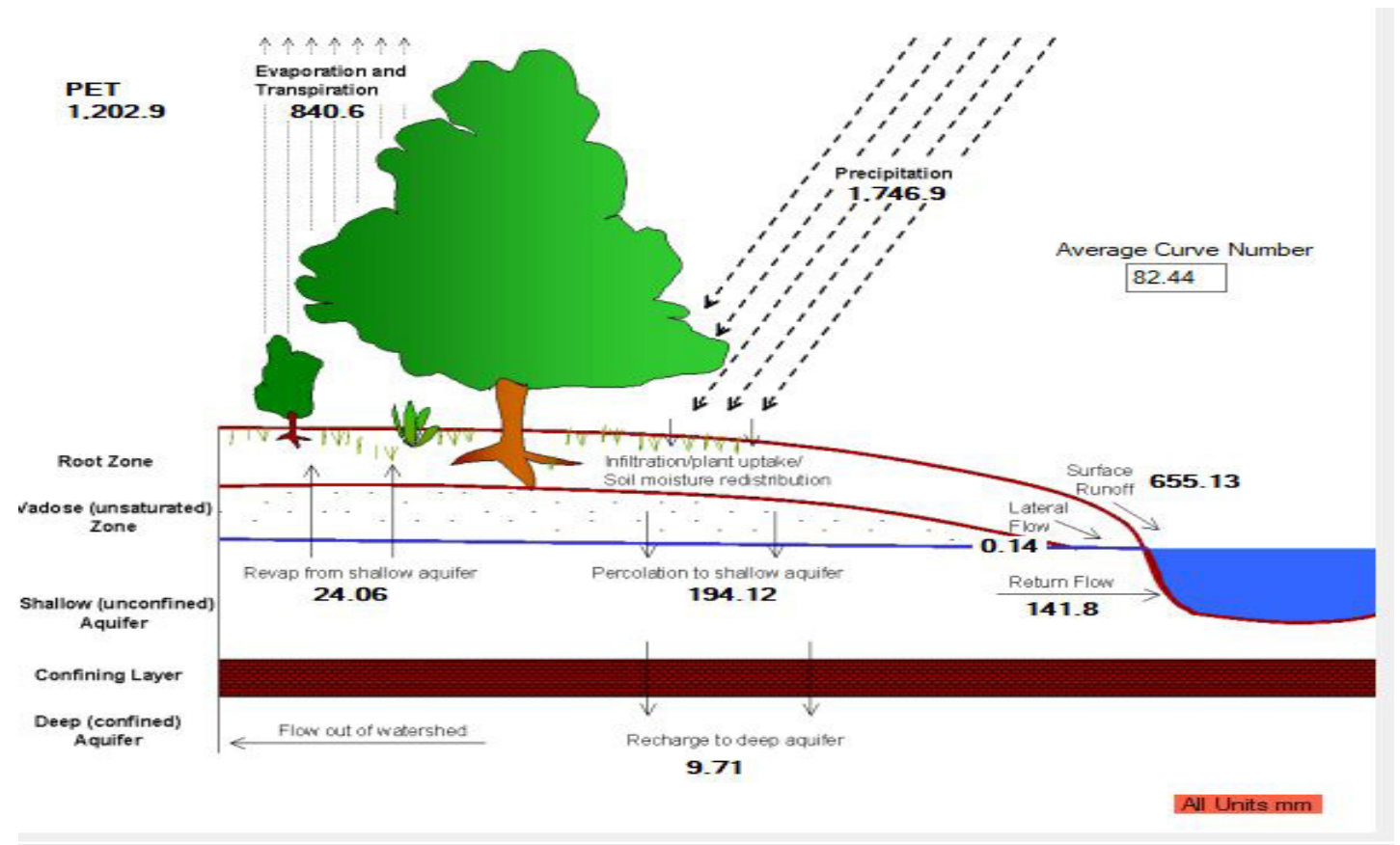

FIGURE 6. Hydrological condition in extreme low precipitation

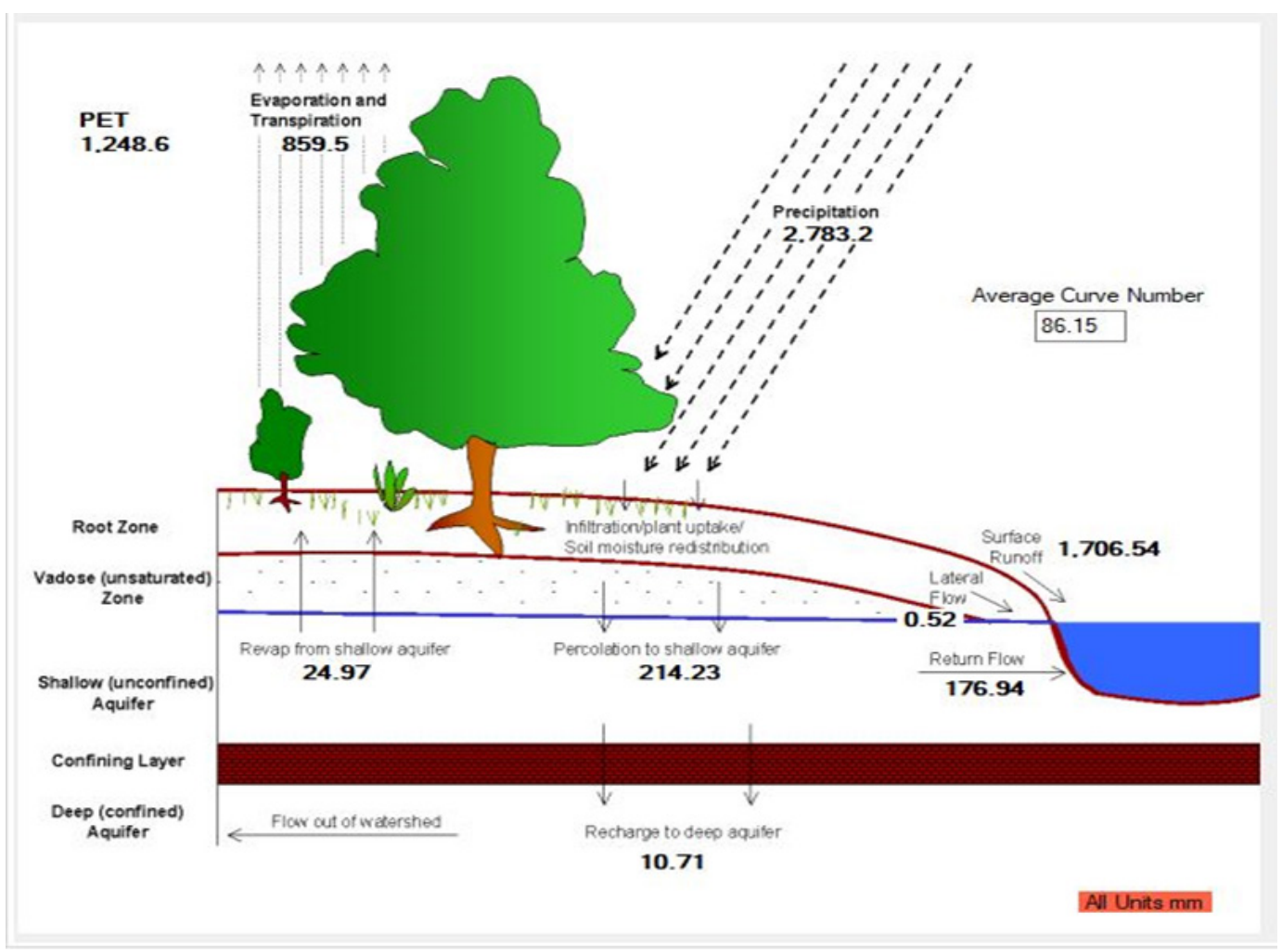

FIGURE 7. Hydrological condition in future land-use (URBN) 


\section{CONCLUSION}

The groundwater recharge was calculated and estimated according to the water balance simulated in SWAT. There were always issues related to groundwater modelling especially the case of assumption of groundwater recharge always $6 \%$ at any kind of environment conditions. In this study, BW SWAT model was simulated with several different scenarios. The estimated groundwater recharge rate from effective rainfall at area of WTP Tg Mas during normal condition, during extreme low precipitation and during normal precipitation and future development environment were $14.6,11.1$, and $7.7 \%$, respectively. In nutshell, based on these findings, the assumption of groundwater recharge was incompatible to use at different climate and environmental condition as shown in current study at BW.

\section{ACKNOWLEDGEMENTS}

We would like to acknowledge the following individual, Mr Azwan, Dr. Nurulhuda, Dr. Rowshon, Mrs Atikahizzaty and Mr Adib for their expertise and assistance throughout all aspects of in this study and for their assistance in writing the manuscript.

\section{REFERENCES}

Burchfield, R.W. 1996. The New Fowler's Modern English Usage. Oxford: Clarendon Press. p. 864.

Chahinian, N., Moussa, R., Andrieux, P. \& Voltz, M. 2005. Comparison of infiltration models to simulate flood events at the field scale. Journal of Hydrology 306(1-4): 191-214.

Department of Irrigation and Drainage Malaysia (DID). 2018. General Climate of Malaysia.

Ebrahim, M.N., Man, H.C., Zawawi, M.A.M. \& Hamzah, M.H. 2019. Prediction of groundwater contaminants from cattle farm using visual modflow. Pertanika Journal of Science and Technology 27(4): 2265-2279.

Federation of Malaysian Consumers Associations (FOMCA). 2009. A Study Report on Groundwater Resources Development Project in the District of Batang Padang, Perak Darul Ridzuan: A Reminder to Malaysia: 'No Charge, No Discharge, Sime Darby Will Be Charged'. Petaling Jaya: Federation of Malaysian Consumers Associations (FOMCA). p. 26.

Golmohammadi, G., Prasher, S., Madani, A. \& Rudra, R. 2014. Evaluating three hydrological distributed watershed models: MIKE-SHE, APEX, SWAT. Hydrology 1(1): 20-39.

Khalilian, S. \& Shahvari, N. 2019. A SWAT evaluation of the effects of climate change on renewable water resources in Salt Lake Sub-Basin, Iran. AgriEngineering 1(1): 44-57.

Kura, N.U., Ramli, M.F., Sulaiman, W.N.A., Ibrahim, S. \& Aris, A.Z. 2018. An overview of groundwater chemistry studies in Malaysia. Environmental Science and Pollution Research 25(8): 7231-7249.

Mali, S.S. \& Singh, D.K. 2016. Groundwater modeling for assessing the recharge potential and water table behaviour under varying levels of pumping and recharge. Indian Journal of Soil Conservation 44(2): 93-102.

Manap, M.A., Nampak, H., Pradhan, B., Lee, S., Sulaiman, W.N.A. \& Ramli, M.F. 2014. Application of probabilisticbased frequency ratio model in groundwater potential mapping using remote sensing data and GIS. Arabian Journal of Geosciences 7(2): 711-724.

Memarian, H., Balasundram, S.K., Abbaspour, K.C., Talib, J.B., Boon Sung, C.T. \& Sood, A.M. 2014. SWATbased hydrological modelling of tropical land-use scenarios. Hydrological Sciences Journal 59(10): 1808-1829.

Malaysian Meteorological Department (MMD). 2018. General Climate of Malaysia.

Niehoff, D., Fritsch, U. \& Bronstert, A. 2002. Land-use impacts on storm-runoff generation: Scenarios of land-use change and simulation of hydrological response in a meso-scale catchment in SW-Germany. Journal of Hydrology 267(1-2): 80-93.

Osang, J., Udoimuk, A.B., Etta, E.B., Ushie, F.O. \& Offiong, N.E. 2013. Methods of gathering data for research purpose and applications using IJSER acceptance rate of monthly paper publication (March 2012 edition-May 2013 edition). IOSR Journal of Computer Engineering (IOSR-JCE) 15(2): 59-65.

Saad, R., Nawawi, M.N.M. \& Mohamad, E.T. 2012. Groundwater detection in alluvium using 2-D electrical resistivity tomography (ERT). Electronic Journal of Geotechnical Engineering 17: 369-376.

Saghravani, S.R., Yusoff, I., Mustapha, S. \& Saghravani, S.F. 2013. Estimating groundwater recharge using empirical method: A case study in the tropical zone. Sains Malaysiana 42(5): 553-560.

Salmiati, N.Z.A. \& Salim, M.R. 2017. Integrated approaches in water quality monitoring for river health assessment: Scenario of Malaysian River. https://www.intechopen. com/books/water-quality/integrated-approaches-in-waterquality-monitoring-for-river-health-assessment-scenarioof-malaysian-.

Schneider, A., Hommel, G. \& Blettner, M. 2010. Linear regression analysis: Part 14 of a series on evaluation of scientific publications. Deutsches Ärzteblatt International 107(44): 776-782.

Srinivasan, R., Zhang, X. \& Arnold, J. 2010. SWAT ungauged: Hydrological budget and crop yield predictions in the Upper Mississippi River Basin. Transactions of the ASABE 53(5): 1533-1546.

Suratman, S. 2014. 6.6. IWRM: Managing the Groundwater Component in Malaysia. In Malaysia Water Forum, Kuala Lumpur, Malaysia. pp. 19-22.

Tahir, W.Z.W.M., Hussin, N.H., Yusof, I., Mamat, K., Latif, J.A. \& Demanah, R. 2014. Integrated assessment of groundwater recharge in the North Kelantan River Basin using environmental water stable isotopes, tritium and chloride data. In International Nuclear Information System 46(33): 1-15.

Tahir, W.Z.W.M., Latif, J.A., Mamat, K., Demanah, R., Saghravani, S.R., Yusof, I. \& Othman, Z. 2009. Preliminary assessment of groundwater recharge using enviromental isotopes investigation $\left({ }^{18} \mathrm{O},{ }^{2} \mathrm{H},{ }^{13} \mathrm{C}\right)$ to support groundwater 
management in the North Kelantan river basin. In International Nuclear Information System. pp. 1-9.

Wooldridge, S., Kalma, J. \& Kuczera, G. 2001. Parameterisation of a simple semi-distributed model for assessing the impact of land-use on hydrologic response. Journal of Hydrology 254(1-4): 16-32.

Department of Biological and Agricultural Engineering Faculty of Engineering

Universiti Putra Malaysia

43400 UPM Serdang, Selangor Darul Ehsan

Malaysia
*Corresponding author; email: mohdazwan@upm.edu.my

Received: 29 March 2020

Accepted: 16 May 2020 